\title{
Как да се справим с острите инсрекции на горните дихателни пътища
}

\author{
Д. Вичева ${ }^{1}$, М. Милков² \\ ${ }^{1}$ Катедра по УНГ-болести, Медицински университет - Пловдив \\ гМедицински университет - Варна, Факултет по дентална медицина
}

Нови проучвания добавят допълнителна тежест към нарастващата интернационална популярност на стандартизирания екстракт om Pelargonium sidoides EPS ${ }^{\circledR} 7630$ $\left(U M C K A L O R^{\circledR}\right)$ в лечението на остри инфекции на дихателните пътища. Анализът на 8 рандомизирани, двойно-слепи клинични проучвания установява, че ЕPs ${ }^{\circledR} 7630$ «е ефективен за облекчаване на симптомите на остър риносинузит и простуда при възрастни», а също така «е ефективен за облекчаване на симптомите на остьр бронхит при възрастни и деиа над 1 година». $\longrightarrow$ стрите инфекции на горни дихателни пътища са огромен социално-икономически проблем. Годишно те костват 5000 милиона евро на Германия, 17 милиарда долара и около 200 милиона болнични дни в САЩ. Данните сочат, че в 60 до $80 \%$ на пациентите с инфекции на ГДП се предписват антибиотици, независимо че етиологията им в над 90\% е вирусна. Последният мета-анализ на Cochrane Collaboration отново оценява ефекта на антибиотиците при неусложнени инфекции на дихателните пътища като граничен, без клинично значение. Обратно на това, страничните ефекти като например бързо увеличаващата се антибиотична резистентност, се проявяват с много по-тежки и чести последствия. В заключение, съотношението между полза и риск е неприемливо.

Ето защо прескрибцията на лекарства с доказан ефект и добра толерантност е от голямо значение за тази индикация. Положителен пример за много добра толерантност и възможност за по-бързо възстановяване е $\operatorname{EPs}^{\circledR} 7630$ (Umckalor $^{\circledR}$ ). Активната субстанция в EPs ${ }^{\circledR}$ 7630 е екстракт от корените на африканското растение Pelargonium sidoides.

Обширни фармакологични, токсикологични и фармацевтични изследвания, както и клинични проучвания с почти 10000 възрастни и деца над 1 година (вкл. над 4000 в плацебо-контролирани, рандомизирани проучвания) са довели до регистрация на специалния екстракт EPs ${ }^{\circledR} 7630$ като лекарствено средство в над 40 страни. Междувременно 2 скорошни мета-анализа, единият от които отново на Cochrane Collaboration показват, че $\mathrm{EPs}^{\circledR} 7630$ е ефективно и отлично поносимо лекарствено средство за лечение на остьр бронхит при възрастни и деца над 1 година $(1,2)$. Учените от 
Cochrane Collaboration обобщават изводите от 8 клинични проучвания с добър дизайн и заключават:

- Umckalor ${ }^{\circledR}$ облекчава симптомите на простуда, остър бронхит и синузит

- Umckalor ${ }^{\circledR}$ е доказано ефективен при възрастни и деца над 1 година

- Без сериозни странични ефекти

- Umckalor ${ }^{\circledR}$ е ефективна алтернатива на антибиотиците при неусожнени остри инфекции на ГДП, която би могла да доведе до намален прием на антибиотици при тази индикация

При пьрви симптоми на инфекция на ГДП Umckalor $^{\circledR}$ е ефективен благодарение на тройния си механизъм на действие - имуномодулиращ, антибактериален и секретолитичен:

1. Имуномодулиращ ефект - стимулира секрецията на цитокини и продукцията на NO от макрофагите, индуцира TNF $\alpha$, активира NK-клетките, цитопротектира посредством стимулиране продукцията на интерферон, потенцира фагоцитозата, оксидативния стрес и интрацелуларната лиза на патогените. Umckalor ${ }^{\circledR}$ индуцира генната експресия на mRNA за синтетаз на NO (iNOS) и серия от цитокини. Това е подкрепа на молекулно ниво на установения имуномодулаторен ефект на Umckalor ${ }^{\circledR}$. Индукция на генната експресия се наблюдава само в инфектирани клетки, което означава, че Umckalor ${ }^{\circledR}$ проявява имуномодулаторен ефект единствено в присъствието на инфектиращ агент, т.е. когато е необходимо.

2. Индиректен и умерен директен антибактериален ефект срещу: Staphylococcus aureus, Strep- tococcus pneumoniae, Streptococcus beta-hemolyticus, Escherichia coli, Klebsiella pneumoniae, Proteus mirabilis, Pseudomonas aeruginosa, Haemophilus influenza. Специалният екстракт EPs ${ }^{\circledR}$ 7630 покрива лигавицата със защитен филм, който предпазва от прикрепянето на патогени и подтиска размножаването на бактериите в лигавицата. Така Umckalor ${ }^{\circledR}$ предотвратява развитието на бактериална суперинфекция.

3. Umckalor ${ }^{\circledR}$ стимулира цилиарната функция с $40 \%$

При първи симптоми на вирусни инфекции на ГДП, когато е късно за имуностимуланти и рано за антибиотици, механизмът на действие на Umckalor® предлага сигурна и безопасна възможност за лечение, особено в детската възраст. Нашият клиничен опит сьщо потвърждава това. Прилагаме Umckalor ${ }^{\circledR}$ в дозировка 10 капки 3 пьти дневно за деца до 6 години и 20 капки 3 пъти дневно за децата до 12 години, като лечението продължава до отшумяване на симптомите, обикновено около 7 дни. За разлика от симптоматичните средства, Umckalor ${ }^{\circledR}$ не само облекчава симптомите на инфекцията, но скъсява и продължителността на заболяването с 2 до 3 дни и е изключително безопасен за децата над 1 година. Най-добри резултати сме наблюдавали при деца от 3 годишна възраст, които посещават детски заведения и страдат почесто от остри вирусни инфекци на ГДП - от 8 до 10 пъти годишно. Целта на терапията с Umckalor ${ }^{\circledR}$ е да се предотврати нуждата от антибиотик при по-голям процент от инфекциите, за да се избегне развитието на резистентност и страничните ефекти от честия прием на антибиотици.

\section{Литература}

1. Timmer A, Guenther J, Ruecker G, Motschall E, Antes G, Kern WV. Pelargonium sidoides extract for acute respiratory tract infectiones. Cochrane Database of Systematic Reviews 2008, Issue 3.Art. No.: CD006323.DOI: 10.1002/14651858.CD006323.pub2.

2. Agbabiaka TB, Guo R, Ernst E. Pelargonium sidoides for acute bronchitis: A systemic review and meta-analysis. Phytomedicine, 2008 May; 15(5): 378-85

\section{За кореспонденция:}

Доц. д-р Диляна ВИЧЕВА, дм

Пловдив 4000

Бул. „Хр. Ботев“ $111 \mathrm{em} .1$

Мобилен тел: 088822367 